\title{
WASTEWATER AND LANDFILL LEACHATE TESTING: ACUTE TOXICITY BIOTEST RESULTS EVALUATION
}

\author{
Anolda ČETKAUSKAITE் $\dot{a}^{\mathrm{a}}$, Milda Zita VOSYLIENË ${ }^{\mathrm{b}}$, Nijole KAZLAUSKIENE $\dot{\mathrm{E}}^{\mathrm{b}}$, Virginija KALCIENE் \\ ${ }^{a}$ Department of Biochemistry and Molecular Biology, Faculty of Natural Sciences, Vilnius University, Čiurlionio \\ g. 21/27, LT-03101 Vilnius, Lithuania \\ ${ }^{b}$ Nature Research Centre, Akademijos g. 2, LT-08412 Vilnius, Lithuania \\ 'Environmental Studies Centre, Faculty of Natural Sciences, Vilnius University, Čiurlionio g., 21/27, LT-03101 \\ Vilnius, Lithuania
}

Submitted 15 May 2014; accepted 15 Dec. 1015

\begin{abstract}
This diverse review discusses biotest species and results scoring systems, which were applied to aquatic toxicity assessment of effluents/wastewater (WW) and landfill leachate (LL). European and American aquatic toxicity testing is reviewed. An example of Lithuanian research data on LL biotesting with aquatic organisms of different phylogenetic and ontogenetic levels is presented. Acute toxicity WW and LL is assessed on the basis of (L(E)C50, acute Toxic Units (TUa), pT values, and, by applying different simple result scoring systems or toxicity thresholds. The differences in legislation and recommendations for biotest application in WW and LL aquatic toxicity testing are compared. It is concluded that WW and LL lowest acute toxicity data (TUa value 0.3 ) should be considered equally as risk to aquatic environment, and technical management decisions should be made. The universal features of toxicity scoring systems, the problems of inventory of old small landfills and cost effective approach are discussed.
\end{abstract}

Keywords: water pollution, aquatic toxicity, landfills, environmental management.

\section{Introduction}

Classification systems for the toxicity of wastewaters, surface waters: publications in Europe, USA and Canada. Bulich (1982) proposed one of the first aquatic bioassay scoring systems. Thereafter, a variety of standard ecotoxicity tests and test batteries were used in Europe and America. These included variety of different systems of classification and toxicological data ranking. Certain recommendations for classification were presented in US EPA, SETAC, HELCOM, and other publications (Tonkes et al. 2005; Huschek, Hansen 2006; Hansen 2007; HELCOM LAND 2007). Other systems were reported in collective publications of researchers (Blaise, Férard 2005) or research articles containing substantial reviews (Ronco et al. 2005; Libralato et al. 2010; Zhang et al. 2012). Short term tests and different systems of classification were applied both for Whole Effluent Toxicity (WET) testing and Whole Effluent Assessment (WEA), (Blaise, Férard 2005); and also, for ambient and in situ surface water quality (SWQ) testing (Den Besten, Munawar 2005; Palma et al. 2008).
Use of biotest data for WEA and pollution permit limit in Europe, USA and Canada. Historically, chemical analysis of effluents or wastewaters (WW) was more developed than biotesting in many European countries. Consequently, permit limits for WW were based on individual constituent chemical permit limit, i.e. concentrations measured by analytical methods (AA or GC), and recognized as toxic from individual chemical toxicity testing. As the EU Water Framework Directive specified good biological and chemical status of receiving waters in EU states, both types of analyses were used in the EU in WW monitoring (Directive 2008/105/EC; European Union 2010a). 2007 OSPAR Report (and guidance document of OSPAR Commission) on WEA presented acute test protocols, which were used in different EU countries. Additionally, nine tests were recommended for freshwaters and seven tests for marine or brackish waters (OSPAR Commission 2007).

In different EU countries, organizations and companies, e.g. Concawe (CONservation of Clean Air and

Corresponding author: Milda Zita Vosylienè

E-mail: zmvosyliene@email.lt 
Water in Europe) and e.g. Arkema (a French multinational chemical producer), the biological species used in most protocols are: i) bacteria Vibrio fischeri, marine spp. (Belgium, Southern Ireland, Portugal, Germany, Netherlands, Sweden, UK, Arkema, Concawe), ii) algae Pseudokirchneriella subcapitata (Belgium, S. Ireland, Portugal, Netherlands, Sweden, UK, Arkema, Concawe), iii) algae Scenedesmus subspicatus, freshwater spp. (Germany), iv) algae Skeletonema costatum, marine spp. (S. Ireland, UK), v) crustacean Daphnia magna, freshwater spp. (Belgium, S. Ireland, Portugal, Germany, Netherlands, UK, Arkema, Concawe), vi) crustacean Nitocra spinipes (Sweden, Concawe), vii) crustaceans Tisbe battagliai and Acartia tonsa, marine spp. (S. Ireland, UK), viii) fish Oncorhynchus mykiss (Belgium, S. Ireland, Germany), ix) Danio rerio fish egg test (Germany), $\mathrm{x}$ ) water plants - Lemna minor (Portugal), (OSPAR Commission 2007). In various countries, different systems of WET or WEA biotest data were applied as an alternative to a chemical approach (and/or permit limits). The MATC - Maximum Acceptable Toxicant Concentration [MATC $=$ geometric mean of NOEC $\times$ LOEC] is used for WW accepting water bodies in USA; Toxic Units - in USA and widely in European countries. In 2005, Germany started to use Lowest Ineffective Dilution (LID), (Federal Ministry for... 2004).

Attempts towards the harmonization of WET and WEA biotesting, and ranking systems. What changes appeared in the recommendations of HELCOM for WET evaluation and WEA after 2007? Based on COHIBA (Control of Hazardous Substances in Baltic Sea Region) Project results, HELCOM MONAS (Helsinki Commission Monitoring and Assessment Group) in 2011 proposed recommendations for WET and WEA, (monitoring of WW) in Baltic Sea region. Different single species biotests (for acute toxicity determination), and evaluation of their toxicity data (by settling toxicity limits) were recommended (HELCOM MONAS 2011). For acute toxicity estimation, the following freshwater tests were recommended according to EN ISO standards: 1) Daphnia magna immobility test (24 and $48 \mathrm{~h}$ ), 2) algae growth inhibition test (short $48 \mathrm{~h}$ version), and 3) luminescent bacteria (15 and 30 min light inhibition) test (HELCOM MONAS 2011). For WEA, additionally, the "test battery" (TB) was recommended, which included at least 2-3 different trophic levels organisms (Fig. 1). The use of only one test species was not recommended for unclear sensitivity reasons (COHIBA 2012).

Currently, no single ISO standard method provides guidance for the scoring of ecotoxicity test results. Usually ISO methods describe how to calculate L/EC50 using a Graphical and Probit Method. The exception is guidance on statistical interpretation of ecotoxicity data of tests applied to characterize soils; it recommends test strategies for the protection of ground and surface waters (ISO
17616:2008). As these guidance methods for ecotoxicity scoring were under development, different countries developed the WET and WEA control systems individually. Thus, variation of ranking scales and toxicity thresholds is substantial [q.v. S. Ireland (Hernan, O’Rourke 2011); Germany (Gartiser et al. 2010); Poland (Mankiewicz-Boczek et al. 2008); Portugal (Mendonça et al. 2009); Italy (Tigini et al. 2011)].

EU Regulations and recommendations for landfill leachates biotesting. Contrary to EU guidelines for WET testing, recent recommendations for landfill leachates (LLs) and waste testing originated from another - Directive on waste (2008/98/EC; European Union 2010b). This Directive lists hazard criteria for waste classification. Waste inherent hazardous property H14 - "ecotoxicity" is defined as a "mirror entry" in this EU document (2008/98/EC). Furthermore, such classification should be based on EU legislation on chemicals, i.e. Council Regulation (EC) No 440/2008, in which for individual chemicals and chemical mixtures hazard for aquatic environment is defined by phrases H410 - H413. Thus, from an initial examination, it appears that the same biotesting principles are valid for wastes as for chemical substances (Thomas et al. 2009). Two types of acute toxicity test batteries (aquatic and soil) are proposed for solid waste and LL in Germany after 2005-2007 European inter-laboratory comparison ring test (Wilke et al. 2008; Moser et al. 2011; Pandard, Römbke 2013). Despite the requirement to cover the traditional three trophic levels with biotest species, the aquatic tests battery for waste testing and hazard classification does not include fish (bioluminescent bacteria, algae and crustacean tests are proposed). This is contrary to Council Regulation (EC) No 440/2008 recommendations where fish, but not fast toxicity screening bioluminescent bacteria ( $V$. fischeri) test can be applied for individual chemicals and their mixtures testing. Figure 1 indicates that for waste ecotoxicity (H 14) characterization, the minimum number of tests needed is six (three tests per LL (or waste eluate) and three - per solid waste), as the eluate, as well as, solid waste tests should be represented (Wuttke, Walther 2013). This eliminates the value of rapid rather than time consuming characterization of waste LL only, especially, when such LL, equally as WW, is discharged to aquatic environment. More detail examination of these Recommendations (Moser, Römbke 2009; Wuttke, Walther 2013) gives evidence of large number recommended tests $(\leq 14$, including significant number of chronic toxicity) and not cost-effective approach for LL urgent characterization. This raises the open question - which test species and data evaluation systems should be used for LLs?

Ecotoxicological reseach of toxicants, WW and LL in Lithuania. Ecotoxicity investigations of various individual toxicants or their mixtures, WW, LLs were undertaken with standard aquatic organisms of different phylogenetic 
levels (bacterium, crustacean, algae, fish (Četkauskaitè, Bražènaitė 2004; Kalcienè, Četkauskaitè 2007); and ontogenetic stages (fish embryos, larvae, adults) (Kazlauskiené, Vosylienè 2008; Svecevičius 2006; Vosylienè et al. 2010; Svecevičius, Kazlauskienè 2011; Montvydienè et al. 2014). Chemical analysis and biotest battery data based ecotoxicological evaluations of municipal WW from regional WW treatment plants of Lithuania cities were implemented in 2007 and 2010 (Manusadžianas et al. 2010; COHIBA
2012). At present, the centralised ecotoxicity and chemical analyses of surface waters, industrial and municipal WW, variably treated LL are performed in the laboratories of Environmental Research Department of the Lithuanian EPA.

In this work, aquatic toxicity test data scoring systems are compared and reviewed. Main purposes of this review are: i) to present an easily usable unified scheme for acute toxicity result evaluation as a summary of

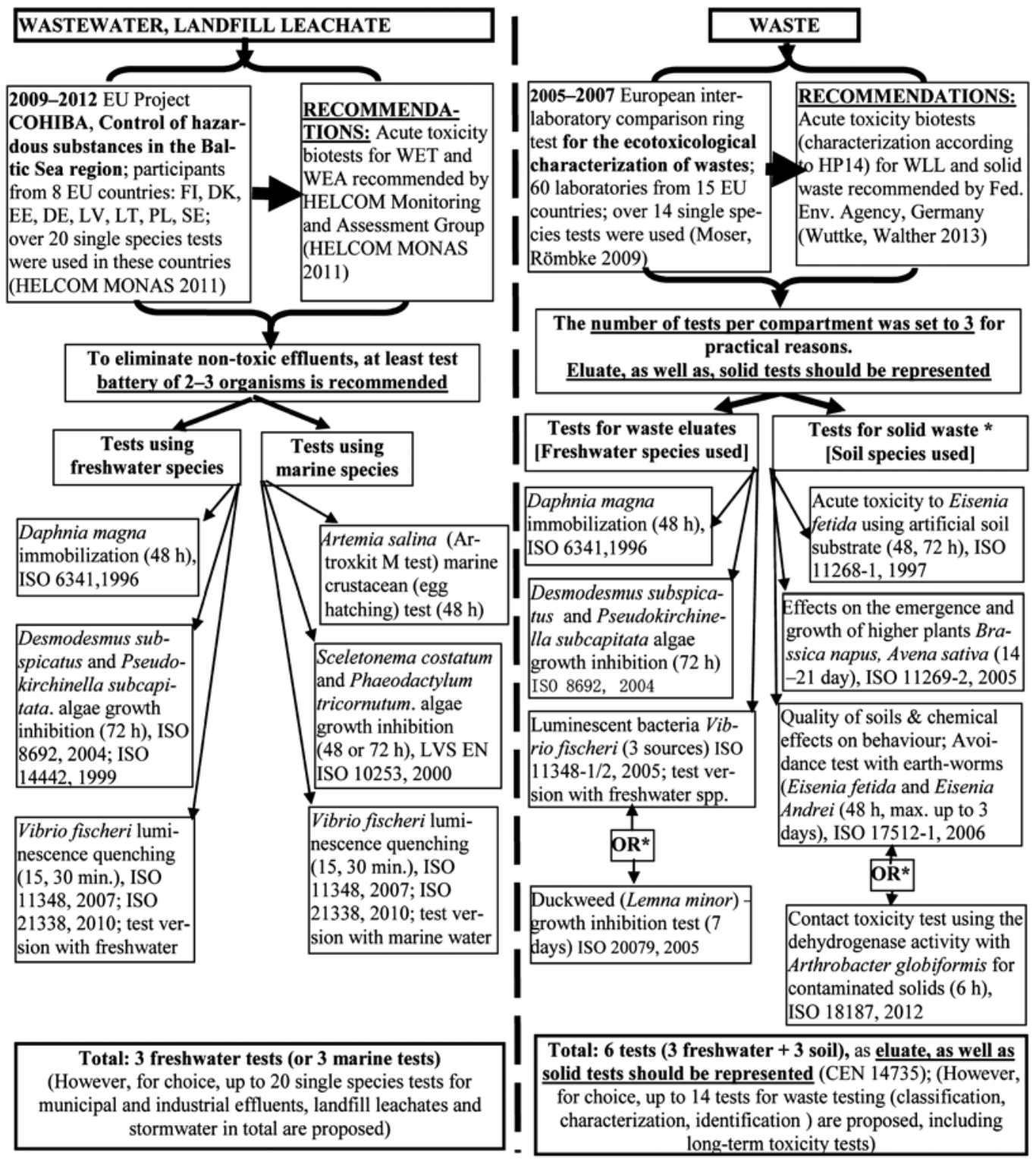

Note: ${ }^{\star}$ a different set of basic test battery is represented in Moser, Römbke (2009) and in 2013

Recommendations of Federal Environmental Agency, Germany (Wuttke, Walther 2013), despite the fact that both were based on the same European ring test for the ecotoxicological characterization of wastes.

Fig. 1. Differences in the number of recommended biotests for toxicity testing of WW, LL, and waste (including waste eluate). (Source: Scheme was compiled on the basis of comparative analysis of the existing literature on 2009-2012 EU Project COHIBA (HELCOM MONAS 2011) and 2005-2007 European inter-laboratory comparison ring test (Moser, Römbke 2009; Wuttke, Walther 2013). References to these ISO standard methods q.v. (HELCOM MONAS 2011; Moser, Römbke 2009; Wuttke, Walther 2013) 
intervals of reference TUa values from WW research; ii) to demonstrate toxicity ranges and lowest values, when samples should be evaluated as toxic; and, iii) to define, which acute toxicity values are appropriate to recommend for LL or WW treatment.

\section{Materials and methods}

Series and monographs related to WET and aquatic toxicity testing (Blaise, Férard 2005; Norberg-King 2005) were assessed. Science Direct and Medline searches "on TU (or LC50) based ecotoxicity classes (categories)", "wastewater permit limits" and others were performed.

ISO standard documents on biotesting and HELCOM guidelines were examined and compared. Experimental articles in the field of WW and LLs toxicity testing were analysed.

The acute toxicity of the Kairiai LL (North Lithuania) after an incident bund wall overflow was studied at the Laboratory of Ecology and Physiology of Hydrobionts (Ecological Physiology and Toxicology Sector) of the Institute of Ecology, Nature Research Centre, Vilnius. The acute toxicity bioassays up to $96 \mathrm{~h}$ duration were carried out using different biotests: higher plant - Lepidium sativum (seed germination), crustacean - Daphnia magna, schrimp Thamnocephalus platyurus, fry and fingerling (juvenile) fish Oncorhynchus mykiss (Kazlauskienè et al. 2004; Šaulienè et al. 2004) (Table 1). Experimental fish acclimatization, handling, physico-chemical water properties, fish care and killing were performed in accordance with recommendations of EU Commission of 18 June 2007 (notified under document number C (2007) 2525) on guidelines for the accommodation and care of animals used for experimental and other scientific purposes (2007/526/EC).

Statistical details for the estimation of L/EC50 and TUa values can be found in (Kazlauskiene et al. 2004; Svecevičius, Kazlauskienè 2011).

\section{Review, results and discussion}

\subsection{Principles of aquatic toxicity classification systems}

Over 40 different schemes for the classification of aquatic toxicity of chemical mixtures, WW, LLs, sediment porewater, elutriates were proposed and used in European States, USA, and Canada, in the period 1982-2012. For example, the principal acute toxicity parameters recommended for WET classification are: standard lethality (LC) - LC50, LC25, immobilization (IC) - IC25 and even NOEC (Not Observed Effect Concentration) of WW, i.e. non-toxic effect, for LID or pT values (Gartiser et al. 2010; Krebs 2005) or other end-points for acute bioassays of 24-96 h duration (HELCOM MONAS 2011). In general, systems of WET classification are based on several approaches: i) comparison of WW samples with clean water controls using dilution methods and simple indices, i.e. constant dilution factor or per cent of WW volume producing an effect; these are determined in diluted samples; ii) using threshold(s) or WET Permit limit(s), expressed in acute Toxic Units, TUa, [TUa $=100 / \mathrm{L}(\mathrm{C}) 50]$, or chronic Toxic Units, TUc, [TUc = 100/NOEC]; and, iii) use of integration of toxicity (amount or strength), by using WW flow rate or toxicity spread area, or by integrating type of toxicity etc. (COHIBA 2010).

First group. Simple scoring systems that use individual indices or scores of toxicity ranking of $\mathrm{WW}$, sediment elutriates, LL fall within following types of data:

a) Dilution factor type data, i.e. LID - defined as the reciprocal value of the lowest ineffective concentration (NOEC) (HELCOM MONAS 2011); LID values were defined as limits for toxicity or dilution factor; e.g. for algae - when "no inhibition $>20 \%$ is ascertained for higher dilution factors"; for sediment elutriates, porewater, $\mathbf{p T}$ value, i.e. negative binary log of the first non-toxic dilution of WW or sediment elutriate (dilutions are performed by factor two) (Krebs 2005); G value lowest dilution factor, when such dilution of WW causes no effect on test-organisms in TB (German regulatory values) (Latif, Licek 2004).

b) Percentage of WW volume, giving certain effect, i.e. PE - percentage effect caused by WW volume (\% WW/v) generating IC50 value in Microtox test (Bulich 1982); or, EC50 value in TB (Tonkes et al. 1999); it can also represent percentage of natural waters, stormwaters, soil percolates volume generating IC50 in Toxkit based biotests (Ronco et al. 2005).

c) $\mathrm{L}(\mathrm{E}) \mathrm{C50}$ based classification for waste (Wilke et al. 2008; Pandard, Römbke 2013).

d) TUa (acute toxic units) as an initial, background scoring value for indices or scales - for WW (HELCOM LAND 2007) and for waste (Lapa et al. 2006). TUa based more sophisticated indices: AvTx - average of toxicity index, i.e. the sum of the endpoint values in TUs divided by the maximum number of possible/used tests (Manusadžianas et al. 2010). Equitox parameter $-\log _{10}(100 /$ EC50) (Vindimian 2005); WET - Whole effluent toxicity index, WET $=\log _{10}\left[1+(\mathrm{n} / \mathrm{N}){ }^{\prime} \Sigma \mathrm{T}\right]$, (where, $\mathrm{n}=$ number of positive toxic responses, $\mathrm{N}=$ number of bioassays used, $\mathrm{T}$ - toxic units); MST - most sensitive test index is an integrated evaluation of WW toxicity by TB; represents the highest TU-score obtained among the tests used in the TB (Manusadžianas et al. 2010).

Second group. Simple scoring systems are based on the thresholds of indices or indices based scales, or 
numerical guidelines for the same data types:

a) Effluent Permit limit (EPA emission limit value) was assigned by the S. Ireland EPA: $<10 \mathrm{TUa}$, i.e. "slightly toxic" or only $\leq 50 \%$ toxic effect can be reached after 10 dilutions of WW (if more, further action needed) (Hernan, O'Rourke 2011).

b) WW acute toxicity categories (five) classified by Irish Shannon Aquatic Toxicity Laboratory (SATL) were in more detail, than the permit limit of Ireland EPA: i) non-toxic (TU < 3); ii) slightly toxic (3-10 TUs); iii) toxic (10-50 TUs); iv) very toxic (50-100 TUs) (Hernan, O'Rourke 2011).

c) WET Index Threshold (or Permit limit) is expressed as follows: a) 0.3 acute toxic unit (TUa), and b) 1.0 chronic toxic unit (TUc) (Ronco et al. 2005).

d) LID - lowest ineffective dilution as a threshold, also named $\mathbf{T}$ - Toxicity limit value. These values for industrial WW at the point of discharge toxicity to fish eggs were usually 2 (sometimes up to 6), umu-test 1.5-3, algae test 16, Daphnia 2-8, bacteria $4-32$ at 10 (or 20) \% effect (HELCOM MONAS 2011).

e) TUa values based five toxicity classes were proposed for WW and natural waters (TB use of data) evaluation: a) no-acute toxicity $(\mathrm{TU}<0.4)$; b) slight acute toxicity $(0.4<\mathrm{TU}<1.0)$; c) acute toxicity $(1.0<\mathrm{TU}<10)$; and, d) high acute toxicity $(10<\mathrm{TU}>100)$, very high acute toxicity (TU > 100), (Ronco et al. 2005); more simple version was used for waste leachates (Lapa et al. 2006).

f) Threshold toxicity (acute and chronic) value for Toxicity identification evaluation (TIE) of effluent (WW) toxicant is $>1.2 \mathrm{TU}$ (giving $95-100 \%$ success for toxicant identification); $<1.2 \mathrm{TU}-$ minimal WW toxicity strength (for WW, which are typically toxic only at full strength) (Goodfellow, McCelloh 2005).

g) EC50 and WW dilution based threshold: If EC50 is $\leq$ the concentration in a $10 \%$ dilution of waste eluate (leachate), then a distinct negative effect is observed (potentially harmful substance in waste) (Pandard, Römbke 2013).

Third group. More complex scoring systems have more sophisticated, derived and complex indices, based on:

a) Integration of toxicity amount using WW flow rate ETI - effluent toxicity index, derived applying PLS (Partial Least Square) regression for TB data and effluent flow rate (Vindimian 2005).

b) Integration of toxicity strength, persistence and specificity in trophic chain - TP - toxic print is WW (effluent) characteristic; it is calculated by multiplying average toxicity AvTx and coefficient n (real number of tests which indicated (geno) toxic results). PEEP index - potentially ecotoxic effect probe, calculated value reflecting ecotoxicity of WW, their persistence and flow rate (Manusadžianas et al. 2010) or WastePEEP in the WASTOXHAZ procedure (Férard, Ferrari 2005).

c) EDAR - effect dilution average ration index (Ronco et al. 2005).

d) Methods integrating types of toxicity (or comparing dependence of relations) - WTI - WW toxicity index based on MSD (Minimum Significant Difference value for deriving Toxicity threshold) (Libralato et al. 2010).

Comparison of preliminary experimental data within the first group of indices of simple scoring systems can assist researchers or monitoring institutions laboratories in their further choice of testing, TB or TIE steps.

Examples presented in the second group show that Permit limits for WW, equally as definitions of what is "very toxic", vary substantially among different systems of evaluation in different countries. Such differences must be resolved.

Third group extended analytical methods and mathematical apparatus bearing methodologies are hardly suitable for routine every day work with substantial numbers of samples in department laboratories of monitoring institutions; they also create difficulties for understanding by municipality decision makers.

For pollution evaluation purposes, simple toxicity scoring systems and thresholds are valuable for following pragmatic reasons: a) less sampling/labour intensity, when there is no need to cover exposure time and/or hazard area evaluation; b) less special mathematical processing in obtaining results; c) easier application for monitoring institutions or department laboratories of routine testing (samples will be sent to large regional laboratories); d) easier understandable for non-specialists members of society or municipality decision makers.

\subsection{WET testing and ranking in Lithuania}

\subsubsection{WET classification systems in Lithuania}

During the period 1996-2011, the systems of the evaluation of effluent acute toxicity were based on following factors:

- WET evaluation performed on the basis of comparison of non-toxic clean water controls with diluted WW; acute toxicity (LC50, EC50, IC50, LT50) values were calculated on the basis of different dilutions of WW and LLs (Kazlauskienè et al. 2004; Vosyliené et al. 2010).

- Ranking of acute toxicity of WW and LLs was achieved using TUs approach (Šaulienè et al. 2004; Manusadžianas et al. 2010), or applying other scoring systems (MST, AvTx) (Manusadžianas et al. 2010). 
It is indicated, that the majority of studies, performed throughout this period, had no wider comparison of experimental data with different toxicity indices and/or thresholds (Fig. 2).

\subsubsection{Toxicity evaluation according individual toxicity scoring schemes and thresholds: an example of $L L$ of Kairiai landfill (Lithuania)}

Comparison of the Kairiai LL data (TUa units) with different TU-based aquatic toxicity scoring systems is

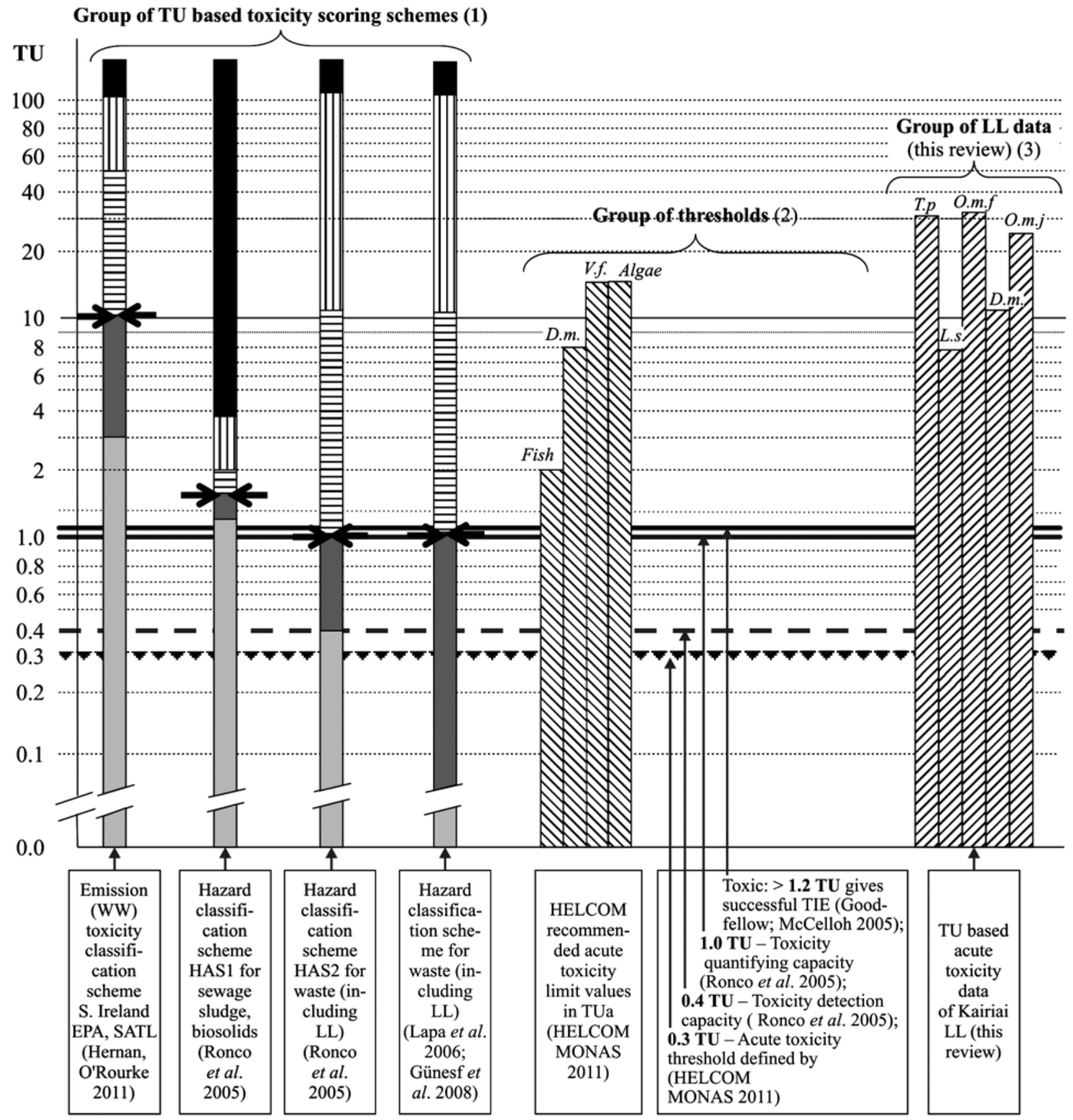

Fig. 2. The scheme of aquatic toxicity of emissions (WW, sewage sludge, LL, etc.) evaluation: the group of hazard classification schemes (1), the group of toxicity thresholds (2) and an example of Kairiai LL acute toxicity data (3), (see Table 1).

Non Toxic

Slightly Toxic

MIIV HELCOM limit values QIIZ Kairiai LL data

-1 Black horizontal opposite arrows crossing bars means the limit between "slightly toxic" and "toxic"

Abbreviations: V.f. - luminescent bacterium Vibrio fischeri; L.s. Lepidium sativum; D.m. - Daphnia magna; T.p. - Thamnocephalus platyurus; O.m.f. - Oncorhynchus mykiss fry; O.m. j. - Oncorhynchus mykiss juveniles (fingerling). 
presented in Table 1. According to L(E)C50 data, the sensitivity of test organisms to leachate is indicated in following sequence: Oncorhynchus mykiss fry > Thamnocephalus platyurus > Oncorhynchus mykiss fingerling > Daphnia magna $>$ Lepidium sativum (roots). LC50 of LL to fish fry comprised $3.0 \%$ and was comparable to T. platyurus LC50-3.22\%. These data confirmed the sensitivity of fish to toxicants at early stages of development and low sensitivity of plant biotests. When the toxicity of the medium is high, all test organisms exposed demonstrated similar high toxicity levels. O. mykiss fry was much more sensitive $(\mathrm{TUa}=33.3)$ than fingerling $(\mathrm{TUa}=23)$ and these values significantly exceeded HELCOM MONAS (2011) recommended acute toxicity limit value for fish $(\mathrm{TU}=2)$. Data obtained with $D$. magna $(\mathrm{TUa}=11.3)$ were closer to the COHIBA (2012) recommended limit value for Daphnia test is $\mathrm{TUa}=8$. The significant sensitivity of shrimp $T$. platyurus biotest that corresponded to data obtained for tested effluents in COHIBA (2012) is noted.

\subsubsection{LL data evaluation using groups of toxicity scoring systems, toxicity limit values and toxicity threshold groups}

In the TUs based scale, it is possible to compare the ranges of WET, waste (including LL) by using acute toxicity (or hazard) classification schemes and groups of the different toxicity thresholds defined toxicity limit values (Fig. 2). The resulting picture gives evidence that ranges indicating what is toxic $(0.3-10 \mathrm{TUs})$ are overlaping in different schemes, thresholds and toxicity limit values. Additionally, it clearly indicates that the Kairiai LL test data: a) exceed different acute toxicity thresholds $(0.3,0.4,1.0,1.2 \mathrm{TU})$; b) significantly exceed HELCOM recommended acute

Table 1. An example of the sensitivity of test organisms of different phylogenetic level and ontogenesis to Kairiai $\mathrm{LL}^{*}$ in acute toxicity tests

\begin{tabular}{|c|c|c|c|c|c|}
\hline Toxicity & $\begin{array}{l}\text { Lepidium sativum } \\
\quad \text { (roots, } 48 \mathrm{~h} \text { ) }\end{array}$ & $\begin{array}{l}\text { Daphnia } \\
\text { magna }\end{array}$ & $\begin{array}{c}\text { Thamnocephalus } \\
\text { platyurus }\end{array}$ & $\begin{array}{l}\text { Oncorhynchus } \\
\text { mykiss fry }\end{array}$ & $\begin{array}{l}\text { Oncorhynchus } \\
\text { mykiss fingerling }\end{array}$ \\
\hline $\begin{array}{l}\text { Primary data } \\
\mathrm{L}(\mathrm{E}) \mathrm{C} 50, \% \mathrm{WW} / \mathrm{v} \\
\text { (Literature source) }\end{array}$ & $\begin{array}{l}12.7 \\
\text { (Kazlauskienè } \\
\text { et al. 2004) }\end{array}$ & $\begin{array}{l}8.83 \\
(\text { Šaulienè et al. } \\
2004)^{\star *}\end{array}$ & $\begin{array}{l}3.22 \\
(\check{S} \text { Saulienè et al. } \\
2004)^{\star *}\end{array}$ & $\begin{array}{l}3.0 \\
\text { (Kazlauskienè et al. } \\
2004)\end{array}$ & $\begin{array}{l}4.35 \\
\text { (Kazlauskienè et al. } \\
\text { 2004) }\end{array}$ \\
\hline $\begin{array}{l}\mathrm{L}(\mathrm{E}) \mathrm{C} 50, \% \text { of } \mathrm{WW} / \mathrm{v} \\
\text { based toxicity category } \\
\text { (Tonkes et al. 1999) }\end{array}$ & $\begin{array}{l}\text { Minor acutely } \\
\text { toxic }(10-100 \% \\
\text { WW/v) }\end{array}$ & $\begin{array}{l}\text { Moderately acutely } \\
\text { toxic }(1-10 \% \\
\text { WW/v) }\end{array}$ & $\begin{array}{l}\text { Moderately acutely } \\
\text { toxic }(1-10 \% \\
\text { WW/v) }\end{array}$ & $\begin{array}{l}\text { Moderately acutely } \\
\text { toxic }(1-10 \% \\
\text { WW/v) }\end{array}$ & $\begin{array}{l}\text { Moderately acutely } \\
\text { toxic }(1-10 \% \\
\mathrm{WW} / \mathrm{v})\end{array}$ \\
\hline $\begin{array}{l}\text { Toxicity class } \\
\text { (Bulich 1982) }\end{array}$ & $\begin{array}{l}\text { Highly toxic } \\
\text { sample }(<25 \%)\end{array}$ & $\begin{array}{l}\text { Highly toxic } \\
\text { sample }(<25 \%)\end{array}$ & $\begin{array}{l}\text { Highly toxic sample } \\
(<25 \%)\end{array}$ & $\begin{array}{l}\text { Highly toxic sample } \\
(<25 \%)\end{array}$ & $\begin{array}{l}\text { Highly toxic } \\
\text { sample }(<25 \%)\end{array}$ \\
\hline TUa & 7.8 & 11.32 & 31.05 & 33.3 & 23 \\
\hline $\begin{array}{l}\text { Toxicity according to } \\
\text { five categories of SATL } \\
\text { (S. Ireland) (Hernan, } \\
\text { O'Rourke 2011) }\end{array}$ & $\begin{array}{l}\text { Slightly toxic } \\
\text { (3-10 TUs) }\end{array}$ & $\begin{array}{l}\text { Toxic } \\
\text { (10-50 TUs) }\end{array}$ & $\begin{array}{l}\text { Toxic } \\
\text { (10-50 TUs) }\end{array}$ & $\begin{array}{l}\text { Toxic } \\
(10-50 \text { TUs })\end{array}$ & $\begin{array}{l}\text { Toxic } \\
(1-50 \text { TUs })\end{array}$ \\
\hline $\begin{array}{l}\text { Toxicity according to } \\
\text { toxicity emission limit of } \\
\text { S. Ireland EPA (Hernan, } \\
\text { O'Rourke 2011) }\end{array}$ & $\begin{array}{l}\text { No real toxicity } \\
(<10 \text { TUs })\end{array}$ & $\begin{array}{l}\text { Toxic } \\
(>10 \text { TUs) } \\
\text { Further testing } \\
\text { and action needed }\end{array}$ & $\begin{array}{l}\text { Toxic } \\
(>10 \text { TUs) } \\
\text { Further testing and } \\
\text { action needed }\end{array}$ & $\begin{array}{l}\text { Toxic } \\
(>10 \text { TUs) } \\
\text { Further testing and } \\
\text { action needed }\end{array}$ & $\begin{array}{l}\text { Toxic } \\
(>10 \text { TUs) } \\
\text { Further testing and } \\
\text { action needed }\end{array}$ \\
\hline $\begin{array}{l}\text { Toxicity above WET acute } \\
\text { TU threshold (Ronco } \\
\text { et al. 2005) }\end{array}$ & 2.6 times & 37.7 times & 103.5 times & 111 times & 76.7 times \\
\hline $\begin{array}{l}\mathrm{pTV}(\mathrm{pT} \text { value) or no } \\
\text { adverse effect dilution } \\
\text { (Krebs 2005) }\end{array}$ & 6 & n.d. & n.d. & 8 & 7 \\
\hline $\begin{array}{l}\text { pT value based Toxicity } \\
\text { category (Krebs 2005) }\end{array}$ & $\begin{array}{l}\text { Extremely } \\
\text { toxic }\end{array}$ & n.d. & n.d. & $\begin{array}{l}\text { Extremely } \\
\text { toxic }\end{array}$ & $\begin{array}{l}\text { Extremely } \\
\text { toxic }\end{array}$ \\
\hline $\begin{array}{l}\text { Toxicity limit values for } \\
\text { industrial WW(HELCOM } \\
\text { MONAS 2011) }\end{array}$ & n.a. & $\begin{array}{l}\text { Toxic } \\
(\mathrm{TU}=8)\end{array}$ & n.a. & $\begin{array}{l}\text { Toxic } \\
(\mathrm{TU}=2)\end{array}$ & $\begin{array}{l}\text { Toxic } \\
(\mathrm{TU}=2)\end{array}$ \\
\hline
\end{tabular}

Notes: n.a. - not applicable; n.d. - not determined.

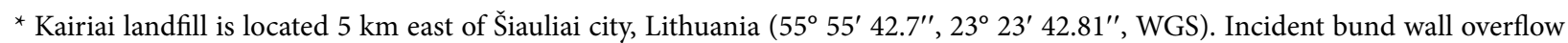
through surrounding channels reached local creek and Ginkūnai pond (2004).

** These L(E)C50, \% primary data are presented with permission from Authors and Publishers from following source: Šauliene et al. (2004). 
toxicity limit values; and, c) represent "toxic" and "extremely toxic" ranges in scoring schemes. This comparison of different toxicity scores systems together with data of interest in TU range can assist for preliminary definition of sample toxicity when such WW or LL is discharged to aquatic environment. Moreover, analysis of scoring/ threshold data indicated a requirement to implement strict toxicity scoring system with low level of acute TU values for category „toxic“ (i.e. mainly 0.3-2 TUa). Thus, it is proposed that samples of WW and LL should be considered equally as toxic starting from a TUa value 0.3 .

\subsection{Different universal features of certain toxicity scoring systems}

More recently, there appeared another important feature of aquatic toxicity data scoring systems - their universality. The same values based scoring systems are used for different origin aquatic samples:

1) pT-values based classification, applied for WWs (Krebs 2005), was used also for sediment materials (porewater, elutriates, extracts, and solid phases);

2) TU based acute toxicity classes initially were proposed for waste dumps and WW; later these were used for aquatic toxicity evaluation (Sauco et al. 2013), with microbiotests in many countries for different environmental samples: natural waters (Greeley et al. 2011), WWs (Kontana et al. 2008; Carbonell et al. 2010); soils, sediments, wastes, biotoxins, etc. Alternatively, TU based classes were used in municipal solid waste (MSW) incineration bottom ash toxicity evaluation (Lapa et al. 2006; Tsiridis et al. 2012);

3) Potential Ecotoxic Effect Probe, PEEP index was used for WET, integrating TB data (TU form), persistence and WW flow rate $(\mathrm{Q})$, was later modified (without Q, etc.) and also applied as WastePEEP for LLs ecotoxicity scoring (Férard, Ferrari 2005).

Universality of aquatic toxicity data scoring systems is also reflected in their application to tests performed with different species. pT-values based scoring system was initially (1987/1988) proposed for the V. fischeri bioluminescent test use only. Later, it was expanded to scoring data of the tests with algae, daphnids, fish (Zha, Wang 2006) and genotoxicity test results (Krebs 2005).

\subsection{Use of fish test for WW and LL toxicity testing}

Different positions exist regarding fish tests used in waste and LLs toxicity testing. Fish tests were not included into 2013 recommendations (ethical considerations) from a 2007 EU ring test of solid waste (including waste leachate) classification, identification and basic characterization because of "animal protection reasons and the large quantity of eluate needed" (Pandard, Römbke 2013). Contrary to this position, the review on species used in the period 1983-2003 showed that fish tests were applied for evaluation of waste LLs (Férard, Ferrari 2005). Aquatic biotests were recommended for testing of substances and mixtures in the Council Regulation (EC) No 440/2008 where fish tests were included. Fish embryo (non-protected life stages) toxicity tests were recognized as suitable in International Workshop 2008 on fish protection in scientific testing (Embry et al. 2010). Fish tests were used in 2009-2012 EU Project COHIBA (HELCOM MONAS 2011). Fish tests were also used for MSW and MSW incineration ash toxicity evaluation (Stiernström et al. 2011).

\subsection{Problems of environmental inventory of old small landfills}

The significant amount of scientific, regulatory, technological, and environmental problems exist today for waste landfills hazard inventory and LLs aquatic toxicity control (Fig. 3). It is realistic to note, that, in the former Soviet Block EU States (fSvBEUS), there exist old MSW landfills from years 1960-1990 (without MSW incineration ash), where the large volume of naturally occurring LLs remains a problem. As there are at least 126 (small) landfill sites in Northern Lithuania, it is not unreasonable to deduce that there are $>1000$ such sites in the fSvBEUS. For example, according to implementation of waste management projects plans, supported by EU, 116 out of 126 small local landfills were closed in North Lithuania regions (Decision of Šiauliai Regional Development Council (Šiaulių Regiono Plètros Taryba 2012)). However, contrary to new MSW big landfills, small regional landfills which were closed with minimal technical facilities (drainage, cover, etc.) should be evaluated and, perhaps, will be waiting best available technologies (BAT): high density polyethylene bottom lining, reverse osmosis (RO) filtration of LL, gas collection systems, etc. As it is not economically viable to transfer the content of small landfills to modern new landfills with BAT, this serious problem should be incorporated into the Agenda for EU Environment Directorate.

Studies on the effect of leachate from a landfill to the underground water (often used for extraction for potable water; or, discharged to rivers) of the surrounding area demonstrated that underground water quality has been compromised by such leachate (Vasarevičius et al. 2005; Hossain et al. 2014). This potential public health hazard to potable water resources cannot be ignored. The landfills could remain a permanent pollution sources for long periods of time after closing (Pablos et al. 2011; Klauck et al. 2013). For example, physico-chemical investigation, phytotoxicity testing and use of battery of biotests (leech, crustacean and fish) showed that the Kairiai landfill closed in 2007 remains a serious source of long-lasting pollution, which adversely affects the neighboring water bodies 
(Svecevičius et al. 2013; Montvydienè et al. 2014). Such problems can be potentially even worse when leachates are percolating into trans-boundary Rivers (i.e. Nemunas River rises in Belarus and the final reaches are shared with Russia).

Various methods (biological, physical and chemical) in fSvBEUS, especially Romania and Poland are described, applied and proposed for treatment of leachate for reducing environmental risk (Białowiec et al. 2007; Kulikowska, Klimiuk 2008; Şchiopu, Gavrilescu 2010; Şchiopu et al. 2012) and even cost-effective methods using anthropogenic soils rehabilitation through phytoremediation (Cretescu et al. 2013). Treatment of the leachates is costly. Şchiopu et al. (2012), (Romania) proposed the use of RO. Whilst it is efficient, these Authors does not advice how to dispose of the RO concentrate (solute) pragmatically. Concentrate treatment in WW treatment plants could be not possible because of heavy metals or thiourea (causing nitrification and other sewage works problems). It should be noted, that new recycling technologies (heavy

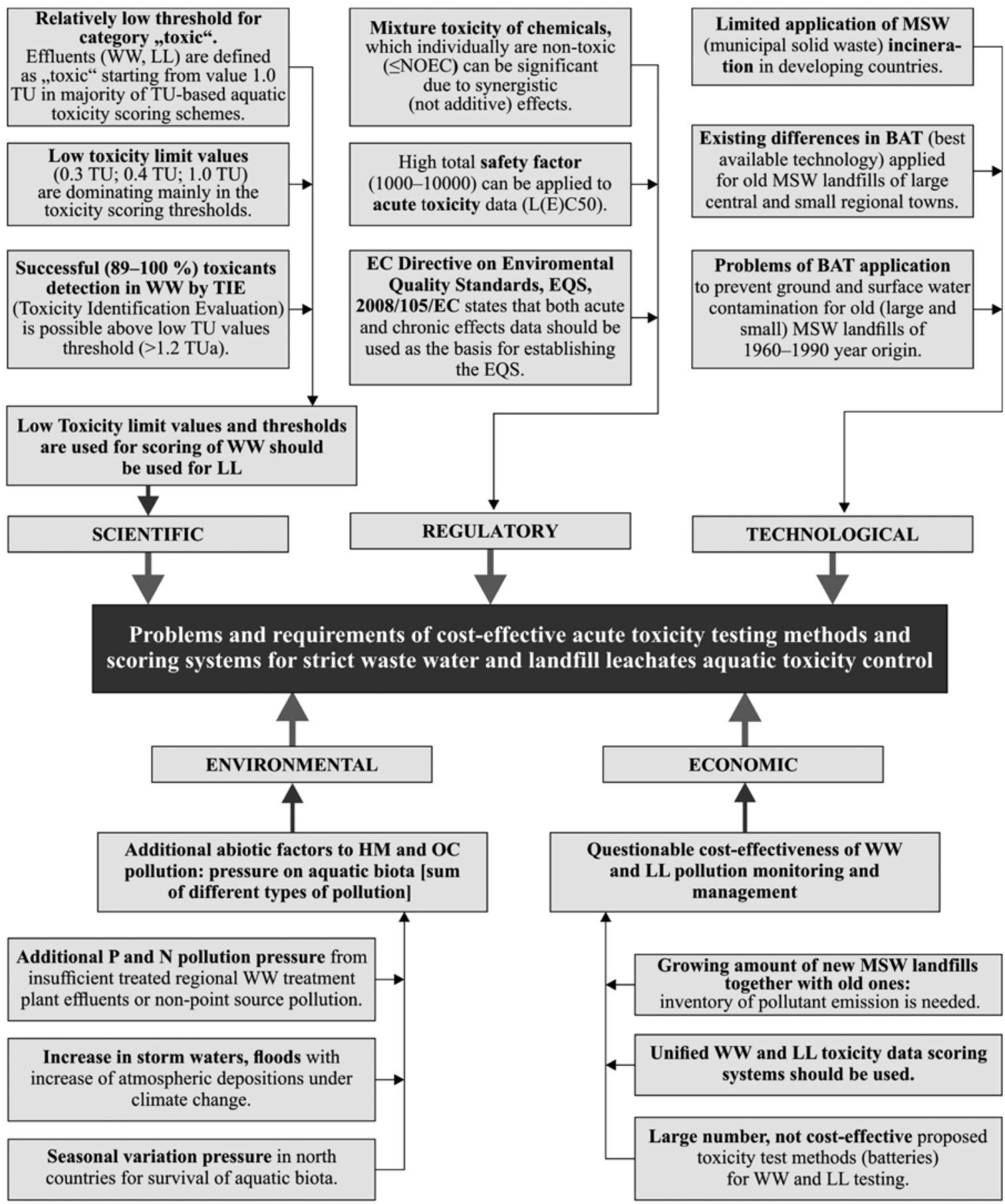

Fig. 3. Pollution of aquatic environment caused by wastewaters and landfill leachates: related problems and multiple evidence of requirement for strict aquatic toxicity scoring and control of emissions (more widely in Review, Results and Discussion section) 
metal bio-mining, combustion gas collection, ethanol production from bio-waste, etc.) are waiting to be applied to waste landfill sites. Otherwise, this growing amount of waste will exacerbate environmental, social, and economic problems (Fig. 3).

\subsection{Waste and LL biotesting: ecotoxicity criteria, recommendations, and problems of cost effective approach}

The characterization of hazard of small regional landfills falls into criterion H15 apart of H14 of WFD 2008/98/EC: "H15. Waste capable by any means, after disposal, of yielding another substance, e.g. a leachate, which possesses any of characteristics listed above". Thus, despite the size and closure status, regional municipal solid waste landfills hazard criteria (primary H14, H15) should be resolved with appropriate test methods. To re-iterate, it is obvious that different EU Directives are applied to water, WW and waste (including LLs), (European Union 2010a, 2010b). Consequently, different recommendations for water, WW and waste (including LLs) acute toxicity testing and data scoring were elaborated and accepted (q.v. Introduction). As mentioned in Introduction, two types of acute toxicity test batteries (aquatic and soil) were proposed for waste and LL in Germany after 2005-2007 European inter-laboratory comparison ring test (Moser et al. 2011; Wuttke, Walther 2013). The aforesaid collectively creates a situation that for aquatic toxicity testing of WW, waste, LL is proposed costly, multiple biotesting, including: multiple species, acute and chronic tests (for water and soil environment) and different scoring systems. Finally, if legally enforceable in EU, these should be accepted for practical use in and will place a financial burden on local municipalities or EPA branch laboratories of EU states, including developing countries with limited resources. Alternatively, the experience of $>30$ years of test use, species selection, data scoring systems for toxicity assessment of water environment (WW, surface water, aquatic life) is much more abundant than waste (including leachates) testing. This experience should be used, and recommendations (for waste testing, classification, water environment testing, etc.) require harmonization together on the lowest cost possible basis. Examples presented in this review show that Permit limits for WW also vary substantially among different systems of evaluation in different countries. For pragmatic reasons the Authors deliberately limited this Review to EU, USA and Canada, but are aware that there are a plethora of other test methods used in Pacific Rim Countries, South America, Africa, Middle East and not least the Commonwealth of Independent States including Russia. The questions arise - which scoring system or thresholds are suitable for correct choice, when toxicity data $(\mathrm{L}(\mathrm{E})$ C50 or TUa, or pTv, LID, etc.) are available from test with two or three species - each from different trophic level and which samples of WW or LL should be indicated as toxic (e.g. see second concluding remark)?

Thus, the globally unified, low cost, acute toxicity testing methods and scoring systems for strict WW and LL toxicity control are of primary need.

\section{Concluding remarks}

Multiple test methods, models and acute toxicity scoring schemes $(>50)$ for WW testing were created in the period 1982-2014. A significant number of acute toxicity classification schemes, thresholds, toxicity limit values (TLVs) were created in the TUa based scale. Additionally, acute toxicity $\mathrm{L}(\mathrm{E}) \mathrm{C} 50$ data can be easily converted to TUa. The analysis of these groups gives multi-evidence that ranges indicating what is slightly toxic - toxic (0.3-10 TUs) are overlapping. This permits comparison and preliminary definition of sample (WW, LL) toxicity within many scoring systems.

On the basis of comparison of the multiple TUa based scoring systems and thresholds, it is proposed that samples of WW and LL should be considered equally as toxic starting from TUa value 0.3 and subsequent decisions for technical management should be undertaken for WW and LL equally. Long-term and not cost effective soil toxicity testing for LL might be omitted. With experience of $>30$ years of biotesting and subsequent data scoring, the aquatic toxicity scoring systems are more elaborated and relevant for toxicity evaluation of effluents (including LL) discharged to aquatic environment.

The legacy of $>1000$ old landfill sites in the fSvBEUS is a major issue requiring very urgent resolution. Concern is related to variably (if any) treated LL, especially of those waste landfills, which are small (and/or medium) size, old (i.e. created in 1970-90's), non-insulated (with high density PE) and have no proper leachate treatment (i.e. reverse osmosis) resulting in slow discharges to aquatic environment.

Authors choice from results (Table 1) is the use of the most sensitive early life stages juvenile fish (i.e. fish fry) for acute toxicity evaluation of LL and WW. However, the reader can choose otherwise. Some of the sensitive biotest methods, when algae, invertebrate and fish are used, are slow and expensive for routine monitoring as compared to analytical chemistry. Hence, having so determined that a discharge is toxic, then a target chemical(s) can be rapidly and cheaply monitored by analytical chemistry, and thus ensure effective environment management.

In view of the gross disparities of biotests and their associated scoring systems usage, the open question remains: which species to use in aquatic samples testing and data evaluation of landfill leachates in different countries? This requires urgent global attention. Hence, the only way 
forward is for the United Nations Specialist Agencies to recommend a global, small set of tests and ideally one only scoring system.

\section{Acknowledgements}

This work was funded by Research Council of Lithuania, Project No. MIP-038/2012. The authors would like to thank M. Richardson, BASIC, formally of Crawley, England, for reading, esteemed comments and improving the English of this article.

\section{References}

Białowiec, A.; Wojnowska-Baryła, I.; Agopsowicz, M. 2007. The efficiency of evapotranspiration of landfill leachate in the soil-plant system with willow Salix amygdalina L., Ecological Engineering 30(4): 356-361. http://dx.doi.org/10.1016/j.ecoleng.2007.04.006

Blaise, C.; Férard, J. F. 2005. Effluent assessment with the PEEP (Potential Ecotoxic Effect Probe), in C. Blaise, J. F. Férard (Eds). Small-scale freshwater toxicity investigations. Vol. 2. Hazard assessment schemes. Dordrecht, the Netherlands: Springer, 69-88.

Bulich, A. 1982. A practical and reliable method for monitoring the toxicity of aquatic samples, Journal Process Biochemistry 17: 1-3.

Carbonell, G.; Fernandez, C.; Tarazona, J. V. 2010. A cost/effective screening method for assessing the toxicity of nutrient rich effluents to algae, Bulletin Environmental Contamination and Toxicology 85(1): 72-78. http://dx.doi.org/10.1007/s00128-010-0035-8

COHIBA. 2010. Control of hazardous substances in the Baltic Sea region. Whole effluent assessment (WEA). Proposed recommendations for the use of toxicity limits. Finish Environment Institute SYKE. 23 p.

COHIBA. 2012. How to control and manage hazardous substances in the Baltic Sea region. Final summary report of the COHIBA Project, in A. Pilke, T. Nakari, E. Schultz, P. Munne, E. Brorström-Lundén, H. Andersson, C. Mathan, F. Marscheider-Weidemann, M. Durkin (Eds.). COHIBA project consortium [online], [cited 20 April 2014]. Available from Internet: www.cohiba-project.net/publications

Council Regulation (EC) No 440/2008 of 30 May 2008 laying down test methods pursuant to Regulation (EC) No 1907/2006 of the European Parliament and of the Council on the Registration, Evaluation, Authorisation and Restriction of Chemicals (REACH), Official Journal of the European Union L 142, 31.5.2008. 739 p.

Cretescu, I.; Pohontu, C.; Iticescu, C.; Cioroi, M.; Ciocinta, R. C.; Bucur, D. 2013. Treatment of landfill leachate using Zea mays and Triticum sp. on antropogenic soils, Journal of Food Agriculture and Environment 11(3,4): 1507-1512.

Četkauskaitè, A.; Bražènaite, J. 2004. Effects of mixtures of oleic acid with chlorinated herbicides on Vibrio fischeri bacteria, Biologija 4: 36-39.

Den Besten, P. J.; Munawar, M. 2005. Ecotoxicological testing of marine and freshwater ecosystems: emerging techniques, trends and strategies. Boca Raton, London, New York, Singapore: CRC Press, Taylor and Francis Group.
Directive 2008/105/EC of the European Parliament and of the Council on environmental quality standards in the field of water policy, Official Journal of the European Communities $\mathrm{L}$ 348/84, 24.12.2008, 84-97.

Directive 2008/98/EC of the European Parliament and of the Council of 19 November 2008 on waste and repealing certain Directives, Official Journal of the European Union OJ L 312/3, 22.11.2008, 3-26.

Embry, M. R.; Belanger, S. E.; Braunbeck, Th. A.; Burgos, M. G.; Halder, M.; Hinton, D. E.; Léonard, M. A.; Lillicrap, A.; Norberg-King, T.; Whale, G. 2010. The fish embryo toxicity test as an animal alternative method in hazard and risk assessment and scientific research, Aquatic Toxicology 97(2): 79-87. http://dx.doi.org/10.1016/j.aquatox.2009.12.008

EU Commission recommendation of 18 June 2007 (2007/526/ EC) on guidelines for the accommodation and care of animals used for experimental and other scientific purposes (notified under document number C (2007) 2525), (text with EEA relevance), Official Journal of the European Union L 197/1, 30.7.2007, 1-89.

European Union. 2010a. Water Environment. Water is for life: How the Water Framework Directive helps safeguard Europe's resources. European Commission Luxembourg: Publications Office of the European Union. Printed in Belgium. 28 p.

European Union. 2010b. Environment. Being wise with waste: the EU's approach to waste management. European Commission Luxembourg: Publications Office of the European Union. Printed in Belgium. 20 p.

Federal Ministry for the Environment, Nature Conservation and Nuclear Safety. 2004. Waste Water AbwV (Ordinance on Requirements for the Discharge of Waste Water into Waters). 121 p. [Promulgation of the New Version of the Waste Water Ordinance of 17 June 2004, coming into force on 1 January 2005]. Germany. Federal Law Gazette BGBl. 2004, Teil I. 1108-1184.

Férard, J. F.; Ferrari, B. 2005. WSATOXHAZ: a bioanalytical strategy for solid wastes assessment, in C. Blaise, J. F. Férard (Eds.). Small-scale Freshwater Toxicity Investigations, Vol. 2. Hazard assessment schemes. Dordrecht, the Netherlands: Springer, 331-375.

Gartiser, S.; Hafner, C.; Hercher, C.; Kronenberger-Schäfer, K.; Paschke, A. 2010. Whole effluent assessment of industrial wastewater for determination of BAT compliance. Part 1: paper manufacturing industry, Environmental Science and Pollution Research 17(4): 856-865.

http://dx.doi.org/10.1007/s11356-009-0289-Z

Günesf, E. H.; Günesf, Y.; Talenle, I. 2008. Toxicity evaluation of industrial and land base sources in a river basin, Desalination 226: 348-356.

http://dx.doi.org/10.1016/j.desal.2007.02.116

Goodfellow, W.; McCelloh, W. 2005. Minimal toxicity necessary for an effective toxicity identification evaluation. Case Study 6.31, in T. Norberg-King (Ed.). Toxicity reduction and toxicity identification evaluations for effluents, ambient waters, and other aqueous media. Pensacola, USA: SETAC Press, 338-344.

Greeley, M. S. Jr.; Kszos, L. A.; Morris, G. W.; Smith, J. G.; Stewart, A. J. 2011. Role of a comprehensive toxicity assessment and monitoring program in the management and ecological recovery of a wastewater receiving stream, Environmental Management 47(6): 1033-1046. http://dx.doi.org/10.1007/s00267-011-9679-3 
Hansen, P. D. 2007. Risk assessment of emerging contaminants in aquatic systems, Trends Analytical Chemistry 26(11): 1095-1099. http://dx.doi.org/10.1016/j.trac.2007.10.001

HELCOM LAND 12/2007. Practical guidance on whole effluent assessment (WEA). Doc. code 4.2/2, in Land-based Pollution Group 12 $2^{\text {th }}$ Meeting, 22-24 May 2007, Espoo, Finland. 31 p.

HELCOM MONAS 15/2011. Helsinki commission, in HELCOM Monitoring and Assessment Group 15th Meeting, 4-7 October 2011, Vilnius, Lithuania. 18 p.

Hernan, R.; O’Rourke K. 2011. Aquatic toxicity testing in Ireland, 2010. Ireland: Shannon. 27 p.

Hossain, Md. L.; Das S. R.; Hossain M. K. 2014. Impact of landfill leachate on surface and ground water quality, Journal of Environmental Science and Technology 7(6): 337-346. http://dx.doi.org/10.3923/jest.2014.337.346

Huschek, G.; Hansen, P. D. 2006. Ecotoxicological classification of the Berlin River system using bioassays in respect to the European Water Framework Directive, Environment Monitoring Assessment 121(1-3): 15-31. http://dx.doi.org/10.1007/s10661-005-9061-0

ISO 17616:2008. Soil quality - Guidance on the choice and evaluation of bioassays for ecotoxicological characterization of soils and soil materials. $11 \mathrm{p}$.

Kalcienè, V.; Četkauskaitè, A. 2007. Environmental and synthetic sulfhydryl group inhibitors: effects on bioluminescence and respiration of Vibrio Fischeri, Alternatives to Laboratory Animals 35: 93-100.

Kazlauskienė, N.; Vosylienė, M. Z.; Marčiulionienė, D.; Montvydiené, D.; Beržinskiené, J. 2004. The assessment of toxicity of Kairiai landfill leachate and water of drainage ditches by use of biological methods, in Proceedings of the International Scientific Conference of 80 years Anniversary of Lithuanian University of Agriculture (Vandens telkiniu apsauga ir valdymas [Protection and management of water bodies]), 23-24 October 2004, Kaunas, Lithuania, 100-109 (in Lithuanian).

Kazlauskienè, N.; Vosylienė, M. Z. 2008. Characteristic features of the effect of $\mathrm{Cu}$ and $\mathrm{Zn}$ mixtures on rainbow trout $\mathrm{On}$ corhynchus mykiss in ontogenesis, Polish Journal of Environmental Studies 17(2): 291-293.

Klauck, C. R.; Rodrigues, M. A. S.; da Silva, L. B. 2013. Toxicological evaluation of landfill leachate using plant (Allium cepa) and fish (Leporinus obtusidens) bioassays, Waste Management Research 31(11): 1148-1153.

http://dx.doi.org/10.1177/0734242X13502388

Kontana, A.; Papadimitriou, C. A.; Samaras, P.; Zdragas, A.; Yiangou, M. 2008. Bioassays and biomarkers for ecotoxicological assessment of reclaimed municipal wastewater, Water Science and Technology 57(4): 947-953. http://dx.doi.org/10.2166/wst.2008.196

Krebs, F. 2005. The pT-method as a hazard assessment scheme for wastewaters, in C. Blaise, J. F. Férard (Eds.). Small-scale freshwater toxicity investigations. Vol. 2. Hazard Assessment Schemes. Dordrecht, the Netherlands: Springer, 115-137.

Kulikowska, D.; Klimiuk, E. 2008. The effect of landfill age on municipal leachate composition, Bioresource Technology 99(13): 5981-5985. http://dx.doi.org/10.1016/j.biortech.2007.10.015

Lapa, N.; Barbosa, R.; Camacho, S.; Monteiro, R.; Fernandes, M. H. F. V.; Oliveira, J. F. S. 2006. Leaching behaviour of a glass produced from a MSWI bottom ash, in P. M. Vilarinho (Ed.). Materials Science Forum 514-516: 1736-1741. http:// dx.doi.org/10.4028/www.scientific.net/msf.514-516.1736
Latif, M.; Licek, E. 2004. Toxicity assessment of wastewaters, river waters, and sediments in Austria using cost-effective microbiotests, Environmental Toxicology 19(4): 302-309. http://dx.doi.org/10.1002/tox.20027

Libralato, G.; Volpi, G. A.; Francesco, A. 2010. How toxic is toxic? A proposal for wastewater toxicity hazard assessment, Ecotoxicology and Environmental Safety 73(7): 1602-1611. http://dx.doi.org/10.1016/j.ecoenv.2010.03.007

Mankiewicz-Boczek, J; Nałęcz-Jawecki, G.; Drobniewska, A. M.; Sumorok, B.; Izydorczyk, K.; Zalewski, M.; Sawicki, J. 2008. Application of a microbiotests battery for complete toxicity assessment of rivers, Ecotoxicology and Environmental Safety 71(3): 830-836.

http://dx.doi.org/10.1016/j.ecoenv.2008.02.023

Manusadžianas, L.; Sadauskas, K.; Vitkus, R. 2010. Comparative study of indices used in toxicity evaluation of effluents, Desalination 250: 383-389. http://dx.doi.org/10.1016/j.desal.2009.09.061

Mendonça, E.; Picado, A.; Paixão, S. M.; Silva, L.; Cunha, M. A.; Leitão, S.; Moura, I.; Cortez, C.; Brito, F. 2009. Ecotoxicity tests in the environmental analysis of wastewater treatment plants: case study in Portugal, Journal of Hazardous Materials 163(2-3): 665-670.

http://dx.doi.org/10.1016/j.jhazmat.2008.07.012

Montvydienė, D.; Marčiulioniene, E. D.; Kazlauskienè, N.; Svecevičius, G.; Jefanova, O.; Žukauskaitė, Z. 2014. Impact of closed Kairiai landfill on the Ginkunai Pond, Lithuania, in The 9th International Conference "Environmental engineering", 22-23 May 2014, Vilnius, Lithuania.

Moser, H.; Römbke, J. 2009. Ecotoxicological characterization of waste - Results and experiences of an European ring test. New York: Springer Ltd. 308 p.

http://dx.doi.org/10.1007/978-0-387-88959-7

Moser, H.; Roembke, J.; Donnevert, G.; Becker, R. 2011. Evaluation of biological methods for a future methodological implementation of the Hazard criterion H14 "ecotoxic" in the European waste list (2000/532/EC), Waste Management Research 29(2): 180-187. http://dx.doi.org/10.1177/0734242X10367844

Norberg-King, T. 2005. Toxicity reduction and toxicity identification evaluations for effluents, ambient waters, and other aqueous media. Pensacola, USA: SETAC Press. 496 p.

OSPAR Commission. 2007. Practical Guidance Document on Whole Effluent Assessment. OSPAR Hazardous Substances Series. Publication Number: 316/2007. 33 p.

Palma, P.; Alvarenga, P.; Palma, V.; Matos, C.; Fernandes, R. M.; Soares, A.; Barbosa, A. R. 2008. Evaluation of surface water quality using an ecotoxicological approach: a case study of the Alqueva Reservoir (Portugal), Environmental Science and Pollution Research 17(3): 703-716. http://dx.doi.org/10.1007/s11356-009-0143-3

Pablos, M. V.; Martini, F.; Fernández, C.; Babín, M. M.; Herraez, I.; Miranda, J.; Martínez, J.; Carbonell, G; San-Segundo, L.; García-Hortigüela, P.; Tarazona, J. V. 2011. Correlation between physicochemical and ecotoxicological approaches to estimate landfill leachates toxicity, Waste Management 31(8): 1841-1847. http://dx.doi.org/10.1016/j.wasman.2011.03.022

Pandard, P.; Römbke, J. 2013. Proposal for a "harmonized" strategy for the assessment of the HP 14 Property, Integrated Environmental Assessment and Management 9(4): 665-672. http://dx.doi.org/10.1002/ieam.1447 
Ronco, A.; Rossini, G. B.; Sobrero, C.; Apartin, C.; Castillo, G.; Diaz-Baez, M. C.; Ramirez, A. E.; Ahumada, I.; Mendoza, J. 2005. The application of hazard assessment schemes using the water toxicity testing battery, in C. Blaise, J. F. Férard (Eds.). Small-scale freshwater toxicity investigations. Vol. 2. Hazard Assessment Schemes. Dordrecht, the Netherlands: Springer, 233-255.

Sauco, S.; Gómez, J.; Barboza, F. R.; Lercari, D.; Defeo, O. 2013. Modified whole effluent toxicity test to assess and decouple wastewater effects from environmental gradients, PLOS ONE 8(6): e66285. http://dx.doi.org/10.1371/journal.pone.0066285

Şchiopu, A.-M.; Gavrilescu, M. 2010. Municipal solid waste landfilling and treatment of resulting liquid effluents, Environmental Engineering and Management Journal 9(7): 9931019.

Şchiopu, A.-M.; Piuleac, C.; Cojocaru, C.; Apostol, I.; Mămălygă, I.; Gavrilescu, M. 2012. Reducing environmental risk of landfills: leachate treatment by reversal osmosis, Environmental Engineering and Management Journal 11(12): 2319-2331.

Stiernström, S.; Hemström; K; Wik, O.; Carlsson, G.; Bengtsson, B-E.; Breitholtz, M. 2011. An ecotoxicological approach for hazard identification of energy ash, Waste Management 31(2): 342-352.

http://dx.doi.org/10.1016/j.wasman.2010.05.019

Svecevičius, G. 2006. Acute toxicity of hexavalent chromium to European freshwater fish, Bulletin of Environmental Contamination and Toxicology 77(5): 741-747.

http://dx.doi.org/10.1007/s00128-006-1126-4

Svecevičius, G.; Kazlauskienè, N. 2011. Behavioral responses in rainbow trout Oncorhynchus mykiss as indicators of sublethal exposure to heavy metals, in D. Cygas, K. D. Froehner (Eds.) "Environmental Engineering", VIII International Conference, Selected Papers, 19-20 May 2011, Vilnius, Lithuania, 374377.

Svecevičius, G.; Kazlauskienė, N.; Slučkaitè, A.; Makaras, T. 2013. Toxicological assessment of the effects of closed landfill on neighboring hydroecosystem, in Proceedings of the 4th International Conference on Environmental Management, Engineering, Planning and Economics (CEMEPE 2013) \& SECOTOX Conference, 24-28 June 2013, Mykonos island, Greece, 799-804.

Šaulienė, I.; Motiekaitytė, V.; Marčiulionienė, D.; Montvydienė, D. 2004. Application of biotests for toxicity evaluation of leachate and toxic tolerant vegetation processes in exploited landfill, in Proceedings of the International Scientific Conference of 80 years Anniversary of Lithuanian University of Agriculture (Vandens telkiniu apsauga ir valdymas [Protection and management of water bodies]). Kaunas, Lithuania. 194-198.

Šiaulių Regiono Plètros Taryba. 2012. Sprendimas Nr. 51/5S25. Dèl Šiauliu regiono komunaliniu atlieku tvarkymo plano 2012-2020 m. patvirtinimo. 2012.05.03, Šiauliai [Decision Regarding Confirmation of the Šiauliai Region Municipal Waste Management Plan for years 2012-2020. Šiauliai, 03.05.2012]. 82 p. (in Lithuanian).
Thomas, D. J. L.; Tyrrel, S. F.; Smith, R.; Farrow, S. 2009. Bioassays for the evaluation of landfill leachate toxicity, Journal of Toxicology and Environmental Health Part B, 12: 83-105. http://dx.doi.org/10.1080/10937400802545292

Tigini, V.; Giansanti P.; Mangiavillano, A.; Pannocchia, A.; Varese, G. C. 2011. Evaluation of toxicity, genotoxicity and environmental risk of simulated textile and tannery wastewaters with a battery of biotests, Ecotoxicology and Environmental Safety 74(4): 866-873.

http://dx.doi.org/10.1016/j.ecoenv.2010.12.001

Tonkes, M.; de Graaf, P. J. F.; Graansma, J. 1999. Assessment of complex industrial effluents in the Netherlands using a whole effluent toxicity (or WET) approach, Water Science Technology 39(1): 55-61. http://dx.doi.org/10.1016/S0273-1223(99)00253-X

Tonkes, M.; den Besten, P. J.; Leverett, D. 2005. Bioassays and tiered approaches for monitoring surface water quality and effluents, in P. J. Den Besten, M. Munawar (Eds.). Ecotoxicological testing of marine and freshwater ecosystems: emerging techniques, trends and strategies. Boca Raton, London, New York: CRC Press, Taylor and Francis Group, 43-86.

Tsiridis, V.; Petala, M.; Samaras, P.; Kungolos, A.; Sakellaropoulos, G. P. 2012. Environmental hazard assessment of coal fly ashes using leaching and ecotoxicity tests, Ecotoxicology and Environmental Safety 75(2): 212-220. http://dx.doi.org/10.1016/j.ecoenv.2012.07.011

Vasarevičius, S.; Čegariova, J.; Sližytè, D. 2005. Investigation and evaluation of landfill leachate permeability in the soil, Journal of Environmental Engineering and Landscape Management 13(3): 108-115.

Vindimian, E. 2005. A multitest index of effluent toxicity by PLS regression, in C. Blaise, J. F. Férard (Eds.). Small-scale freshwater toxicity investigations. Vol. 2. Hazard assessment schemes. Dordrecht, the Netherlands: Springer, 89-114.

Vosylienè, M. Z.; Kazlauskienè, N.; Baršienè, J.; Andreikènaitè, L.; Milukaite, A.; Taujanskis, E. 2010. Ecotoxicity and genotoxicity relating to fish in wastewaters discharged from the Vilnius treatment plant, Water Science and Technology 62(4): 859-865. http://dx.doi.org/10.2166/wst.2010.916

Wilke, B. M.; Riepert, F.; Koch C.; Kühne T. 2008. Ecotoxicological characterization of hazardous wastes, Ecotoxicology and Environmental Safety 70(2): 283-293. http://dx.doi.org/10.1016/j.ecoenv.2007.10.003

Wuttke, J.; Walther, M. 2013. Recommendations for the ecotoxicological characterization of wastes. Section 1.5 Municipal waste management, hazardous waste, focal point to the Basel Convention. Federal Environment Agency, Germany. 27 p.

Zha, J.; Wang, Z. 2006. Acute and early life stage toxicity of industrial effluent on Japanese medaka (Oryzias latipes), Science of the Total Environment 357(1-3): 112-119. http://dx.doi.org/10.1016/j.scitotenv.2005.04.038

Zhang, X.; Wiseman, S.; Giesy, J. 2012. Toxicology of water, in A. Luch (Ed.). Molecular, clinical and environmental toxicology. Experientia Supplementum 101, Basel AG Springer, 1-27. http://dx.doi.org/10.1007/978-3-7643-8340-4_2 
Anolda ČETKAUSKAITĖ. Dr, retiree. PhD in Biology (Biochemistry, bioenergetics), Institute of Biochemistry of Republic of Lithuania, 1984. Senior research biochemist, 1988. Assoc. Prof., Department of Biochemistry and Biophysics, Faculty of Natural Sciences, Vilnius University, 1999-2012; affiliated Assoc Prof., Dept. Biochem. Mol. Biol., 2013. Scientific publications: 54. Presentations in over 20 international conferences, workshops, symposiums. Member of SETAC 2000-2010. Author of textbooks in Lithuanian language for bachelor and master degree university students: 1) Četkauskaitè A. Ecotoxicology: Mechanisms of Action of Chemical Compounds. Textbook, ISBN 9986-19-335-4, Vilnius: Vilnius University Publishing House, 1999. 452 p.; 2) Četkauskaite A. Biochemical Toxicology. Textbook ISBN 978-9955-25-457-7, Kaunas: Kaunas University of Technology Publishing House “Technologija”, 2008, 163 p.; 3) Četkauskaite A. Ecological Biochemistry (Part I). Textbook in CD format, Kaunas: Kaunas University of Technology Publishing House “Technologija”, 2008,56 p. Research interests: ecotoxicology, aquatic toxicology, mechanisms of action of individual xenobiotics and their mixtures, QSAR, molecular biomarkers of xenobiotic toxicity, fate of xenobiotics in the environment.

Milda Zita VOSYLIENĖ. Dr, retiree. Laboratory of Ecology and Physiology of Hydrobionts. Institute of Ecology Nature Research Centre. PhD of Biomedical sciences, (physiology), Institute of experimental and clinical medicine, 1968. Publications during the last 10 years: 34 scientific publications in journals and books involved into the ISI list and 12 articles published in journals involved into "ISI Web of Science". During the last 12 y participated with the presentations in over 20 international scientific seminars, workshops, and conferences. Research interests: ecological physiology, fish physiology, ichthyohematology, ecotoxicology. 2007 - Lithuanian Science Award for the cycle "The use of biological tests to assess aquatic toxicity" (1986-2006), with co-authors.

Nijolė KAZLAUSKIENĖ. Dr, Laboratory of Ecology and Physiology of Hydrobionts. The head of Ecological physiology and toxicology sector Institute of Ecology Nature Research Centre. Dr of Biomedical sciences (physiology), Sechenov name Institute of Evolutionary biochemistry and physiology (Russia), 1987. Senior scientific worker, 2003. Publication: 97 scientific publications. Participated with the presentations in over 40 international scientific seminars, workshops, conferences, congresses and symposiums. Research interests: ecological physiology, fish physiology, ecotoxicology, ecology. 2007 Lithuanian Science Award for the cycle "The use biological tests to assess aquatic toxicity" (1986-2006), with co-authors.

Virginija KALCIENĖ. Dr, lecturer at the Centre for Ecology and Environment Research, Vilnius University. PhD of Physical sciences (biochemistry), Vilnius University, 2011. Junior scientific worker at Department Biochemistry and Biophysics of Vilnius University, since 2009 up to 2011. Publications: 2 scientific publications. Presentations in 7 scientific conferences. Research interests: ecotoxicology, environmental risk assessment of chemicals, environmental chemistry, ecology. 